\title{
Pengelompokan Komentar Dataset Sentipol dengan Modified K-Means Clustering
}

http://dx.doi.org/10.28932/jutisi.v6i3.3006

\author{
Ruddy Cahyanto ${ }^{\otimes \# 1}$, Antonius Rachmat Chrismanto ${ }^{* 2}$, Danny Sebastian*3

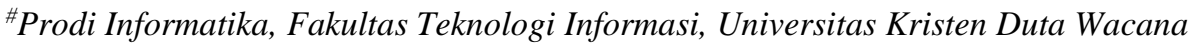 \\ Jl. Dr. Wahidin Sudirohusodo no. 5-25, Yogyakarta \\ ${ }^{1}$ ruddy.ceti.ukdw.ac.id \\ 2anton@ti.ukdw.ac.id \\ ${ }^{3}$ danny. sebastianestaff.ukdw.ac.id
}

\begin{abstract}
Clustering is a technique in data mining that groups data sets into similar data clusters. One of the algorithms that is commonly used for clustering is K-Means. However, the K-Means algorithm has several weaknesses, one of them is the random factor in initial centroid selection, so that cluster result is inconsistent even though it is tested with the exact same data. The Modified K-Means algorithm focuses on selecting the initial centroid to overcome inconsistencies of cluster results in the K-Means method. The test was conducted using Sentipol dataset and only focused on comment data. Furthermore, the specified number of clusters is three based on the number of existing comment labels (positive, negative, and neutral). According to testing results, Modified K-Means algorithm produces better purity value than K-Means algorithm. Modified K-Means algorithm produces average of purity value 0,42 , while $\mathrm{K}$-Means produces average of purity value 0,391 . Meanwhile, from testing related to random factors conducted 5 times with the same attributes and test data, the results of the cluster on the Modified K-Means algorithm did not change, so automatically the resulting purity value was also the same. Whereas in the K-Means algorithm, the cluster results always change in each test, so the result of purity value is also likely to change.
\end{abstract}

Keywords - clustering; Sentipol Dataset; K-Means; Modified KMeans;

\section{Pendahuluan}

\section{A. Latar Belakang}

Dataset Sentipol merupakan dataset sentimen komentar pada kampanye pemilu presiden tahun 2014 yang diambil dari facebook page [1]. Dataset Sentipol berisi 3400 komentar dari 68 status. Selain itu, komentar-komentar yang ada juga telah diberi label positif, negatif dan netral. Sebelumnya telah dilakukan penelitian mengenai klasifikasi pada dataset sentipol, namun belum pernah dilakukan penelitian mengenai clustering.

Clustering merupakan salah satu teknik dalam data mining yang mengelompokkan suatu himpunan data ke dalam kelompok-kelompok (clusters) data yang serupa [2]. Metode yang umum digunakan dalam clustering adalah $K$ Means. K-Means sering digunakan dalam clustering karena kemudahan penggunaannya. Namun, kualitas hasil akhir clustering dengan menggunakan algoritma $K$-Means sangat bergantung pada pemilihan centroid (titik pusat cluster) awal [3]. Pada algoritma K-Means, pada umumnya pemilihan centroid awal dilakukan secara random, sehingga memungkinkan hasil akhir clustering berbeda meskipun menggunakan data uji yang sama [4]. Selain itu, jika centroid awal yang dipilih buruk, maka cluster yang dihasilkan bisa sangat tidak optimal. Berdasarkan kelemahan K-Means tersebut, pada penelitian ini akan dilakukan modifikasi pemilihan centroid awal dengan menggunakan algoritma Modified K-Means [5].

Tujuan utama dari penelitian ini yaitu membangun sistem clustering dengan menggunakan dataset sentipol dan algoritma Modified K-Means, setelah itu dilakukan perbandingan dengan algoritma K-Means biasa. Perbandingan dilakukan pada akurasi dan konsistensi dari cluster yang dihasilkan. Sedangkan alat ukur pengujian yang akan digunakan adalah nilai purity dari cluster yang dihasilkan. Nilai purity sendiri dapat dihitung dengan cara menjumlahkan dokumen (komentar) yang berada di cluster yang tepat lalu dibagi dengan jumlah keseluruhan komentar [6].

Penelitian ini memberikan kontribusi dengan memberikan beberapa manfaat baik dari sisi algoritma maupun dataset yang digunakan. Penggunaan algoritma Modified K-Means ternyata memang dapat mengatasi inkonsistensi hasil cluster pada metode $K$-Means biasa dan menghasilkan nilai purity yang lebih baik.

\section{B. Rumusan Masalah}

Berdasarkan pada latar belakang masalah yang telah diuraikan, permasalahan tersebut dapat dirumuskan ke dalam beberapa poin, yang pertama yaitu bagaimana penerapan Modified K-Means dalam mengklasterisasi data 
komentar pada dataset sentipol untuk mendapatkan hasil cluster yang konsisten? Kemudian yang kedua, bagaimana perbandingan hasil clustering pada Modified K-Means dan metode K-Means? Dan yang terakhir yaitu bagaimana hasil analisis clustering data komentar pada dataset sentipol berdasarkan nilai purity yang dihasilkan?

\section{Tujuan Penelitian}

Berdasarkan pada rumusan masalah yang ada, terdapat tiga tujuan yang ingin dicapai dari penelitian ini. Tujuan pertama yaitu menerapkan Modified K-Means dalam mengklasterisasi data komentar sentipol untuk mendapatkan hasil cluster yang konsisten. Kedua, membandingkan hasil clustering pada metode Modified K-Means dan K-Means. Kemudian yang terakhir yaitu menganalisis hasil clustering data komentar sentipol berdasarkan nilai purity yang dihasilkan.

\section{Tinjauan Pustaka}

Hingga saat ini, sudah ada beberapa penelitian yang dilakukan mengenai algoritma $K$-Means dan Modified $K$ Means. Penelitian yang pertama yaitu mengenai perbandingan metode K-Means dan Hierarchical Agglomerative Clustering pada pengelompokan dokumen teks. Fokus penelitian ini yaitu membandingkan tingkat akurasi hasil clustering dari kedua metode dengan melakukan jumlah data uji yang bervariasi. Dari penelitian ini, metode $K$-Means dapat menghasilkan akurasi yang lebih baik pada jumlah data uji yang besar [7].

Penelitian selanjutnya lebih berfokus pada efisiensi dari proses clustering yang dilakukan. Dengan menggunakan metode K-Means yang dimodifikasi pada pemilihan centroid awalnya, didapatkan waktu pemrosesan yang lebih efisien dari metode K-Means biasa. Selain itu, iterasi yang diperlukan pada proses clustering juga semakin sedikit [5].

Selain kedua penelitian tersebut, masih terdapat penelitian lain mengenai perbandingan metode K-Means dan Modified K-Means pada kumpulan data yang besar. Dari hasil pengujian yang dilakukan dengan jumlah data yang bervariasi mulai dari 300, 400, 500, hingga 600 data, algoritma Modified K-Means lebih efisien dari segi waktu pemrosesan yang dibutuhkan jika dibandingkan dengan algoritma $K$-Means biasa [8].

Dari beberapa penelitian di atas, algoritma $K$-Means maupun Modified K-Means dapat digunakan pada jumlah data uji yang besar. Selain itu, algoritma Modified K-Means juga memerlukan waktu pemrosesan yang lebih sedikit dibandingkan K-Means biasa. Namun, penelitian ini tidak akan berfokus pada efisiensi dari proses clustering, melainkan akan lebih berfokus pada salah satu kelemahan dari metode $K$-Means yaitu konsistensi dan akurasi dari cluster yang dihasilkan. Selain itu, salah satu pembeda antara penelitian ini dengan penelitian-penelitian sebelumnya terletak pada dataset yang digunakan, di mana sebelumnya belum pernah dilakukan clustering pada dataset sentipol.

\section{METODE PENELITIAN}

\section{A. Prosedur Penelitian}

Tahapan-tahapan yang dilakukan pada penelitian ini adalah sebagai berikut:

1. Melakukan perumusan serta batasan-batasan masalah terkait penelitian yang dilakukan.

2. Melakukan pemahaman tentang penelitian terkait clustering yang menggunakan algoritma Modified $K$ Means.

3. Melakukan perancangan sistem clustering yang akan dibangun, meliputi perancangan alur kerja sistem, perancangan antarmuka hingga perancangan database.

4. Melakukan perancangan pengujian yang akan dilakukan.

5. Melakukan pengujian konsistensi dan nilai purity dari cluster yang dihasilkan.

6. Pengambilan kesimpulan berdasarkan hasil pengujian

\section{B. Perancangan Alur Kerja Sistem}

Tahapan-tahapan pada sistem clustering yang dibangun akan dijelaskan dalam beberapa poin berikut:

1) Input Data: Tahap pertama dalam sistem clustering adalah menginputkan data yang akan dilakukan clustering. Dalam penelitian ini, data yang digunakan adalah file dataset sentipol yang berekstensi .csv dan hanya berfokus pada data komentar saja. Setelah file dataset dimasukkan ke dalam sistem, sistem akan mengambil komentar dan label komentar untuk kemudian disimpan ke dalam database.

2) Normalisasi: Proses selanjutnya adalah normalisasi teks komentar. Normalisasi dilakukan untuk menghilangkan objek-objek yang tidak dibutuhkan seperti alamat web (url), tagar, mention user lain, dan sebagainya. Selain menghapus objek-objek yang tidak dibutuhkan, pada proses normalisasi ini juga dilakukan proses pengubahan kata-kata singkatan serta kata "alay" menjadi kata yang utuh dan baku.

Beberapa normalisasi yang akan dilakukan adalah sebagai berikut [9]:

- Case folding atau mengubah huruf kapital ke huruf non-kapital.

- Menghapus url atau alamat web.

- Menghapus tagar atau hashtag, contohnya \#salam2jari, \#salam1jari, dll.

- Menghapus mention, sebagai contoh @ruddy, @jono, dll.

- Menghapus emoticon, contohnya :v, :p, :poop:, dll.

- Menghapus tanda baca.

- Menghapus angka.

- Mengubah kata dengan huruf-huruf yang berulang, misalnya "aduuuuhh" menjadi "aduh".

- Mengubah singkatan dan kata-kata alay menjadi kata baku, misalnya "mantapz" menjadi "mantap", "yg" menjadi "yang".

Pada proses pengubahan singkatan dan kata-kata alay menjadi kata yang baku, digunakan Kamus Besar Bahasa 
Alay (KBBA) yang dibangun sendiri berdasarkan temuan kata-kata alay yang terdapat pada dataset sentipol. Untuk memperjelas proses normalisasi yang dilakukan, berikut ini contoh beberapa komentar sebelum dan setelah dilakukan normalisasi seperti yang bisa dilihat pada Tabel I.

TABEL I

CONTOH KOMENTAR SEBELUM DAN SESUdAH NORMALISASI

\begin{tabular}{|l|l|}
\hline \multicolumn{1}{|c|}{ Sebelum Normalisasi } & \multicolumn{1}{c|}{ Sesudah Normalisasi } \\
\hline Enak, di lhat tapa beban & enak di lihat tanpa beban \\
\hline Tapi ingat 98 gk pak? & tapi ingat nggak pak \\
\hline yakiiinn..menaaanng??? & yakin menang \\
\hline$:^{*}$ & \\
\hline $\begin{array}{l}\text { http://www.youtube.com/watch? } \\
\text { v=HAXObaH8x }\end{array}$ & \\
\hline
\end{tabular}

3) Tokenisasi: Proses selanjutnya adalah tokenisasi atau pemenggalan kalimat menjadi kata per kata. Pada proses ini data komentar yang ada di dalam database akan dipecah menjadi kata per kata berdasarkan delimiter seperti tanda baca (titik, koma, dll), whitespace (spasi, tab, new line), dan lain sebagainya [10].

4) Stopword Removal: Setelah dilakukan tokenisasi dan didapatkan kata per kata dari tiap dokumen, proses selanjutnya adalah stopword removal atau proses penghapusan kata-kata yang tidak penting atau kurang memiliki makna. Proses ini sendiri dilakukan dengan cara menghapus kata-kata yang sama dengan kata-kata yang terdapat di stopword list [11]. Stopword list sendiri berisi kata-kata yang tidak memiliki arti penting dan tidak diperlukan untuk proses selanjutnya dalam clustering. Untuk lebih jelasnya, contoh sebagian kata-kata yang termasuk dalam stopword list dapat dilihat pada Tabel II. Data stopword list ini dibangun sendiri berdasarkan katakata umum dari KBBI dan dari dataset sumber.

TABEL II

CONTOH KATA DALAM DAFTAR STOPWORD BAHASA INDONESIA

\begin{tabular}{|l|l|l|l|}
\hline \multicolumn{4}{|c|}{ Stopword List } \\
\hline Ada & Bagai & Cara & Dari \\
\hline Adalah & Bagaikan & Caranya & Daripada \\
\hline Adanya & Bagaimana & Cukup & Datang \\
\hline Adapun & Bagaimanakah & Cukupkah & Dekat \\
\hline Agak & Bagaimanapun & Cukuplah & Demi \\
\hline Agaknya & Bagi & Cuma & Demikian \\
\hline Agar & Bagian & Dahulu & Demikianlah \\
\hline Akan & Bahkan & Dalam & Dengan \\
\hline
\end{tabular}

5) Feature Generation: Setelah proses tokenisasi dan stopword removal, maka telah didapatkan kata-kata yang memiliki makna dan arti penting untuk kemudian dilakukan pengklasteran atau pengelompokkan. Namun, kata-kata yang ada masih belum bisa dilakukan penghitungan jarak untuk kemudian dikelompokkan ke dalam cluster yang sesuai. Oleh karena itu, pada tahap ini dilakukan pembobotan pada setiap kata sehingga bisa dilakukan penghitungan jarak berdasarkan bobot masing-masing kata. Pemberian bobot pada tiap kata (features) juga dibutuhkan dalam proses feature selection, dimana kata-kata yang mewakili keseluruhan kata pada proses clustering dipilih berdasarkan bobot tertinggi sesuai dengan persentase feature selection yang ditentukan. Selain pada proses feature selection, bobot ini juga digunakan pada proses pengelompokan cluster untuk menghitung jarak terdekat antar dokumen/data.

Metode yang digunakan untuk melakukan pembobotan pada penelitian ini adalah TF-IDF (Term Frequency Inverse Document Frequency). Metode ini akan digunakan untuk mendapatkan bobot setiap kata pada dokumen. Persamaan 1 dan 2 merupakan rumus dari penghitungan TFIDF [12].

$$
\begin{gathered}
T F-I D F(w, d)=T F(w, d) * I D F(w) \\
I D F(w)=\log (|D| / D F(w))
\end{gathered}
$$

$$
\begin{aligned}
& \text { Dimana: } \\
& T F(w, d)=\text { jumlah kata yang muncul pada dokumen } \\
& d \\
& I D F(w) \quad=\text { frekuensi invers dokumen kata } w \text { dari } \\
& \text { jumlah dokumen yang ada } \\
& D F(w) \quad=\quad \text { jumlah dokumen yang memuat kata } w \\
& D \quad=\text { jumlah seluruh dokumen }
\end{aligned}
$$

6) Features Selection: Setelah pemberian bobot dengan metode TF-IDF dan menggabungkan kata-kata yang sama, proses berikutnya adalah features selection atau pemilihan kata-kata yang nantinya akan mewakili keseluruhan kata dalam proses clustering. Kata-kata atau features yang telah diberi bobot pada proses features generation akan dipilih beberapa saja berdasarkan nilai persentase features selection yang ditentukan oleh user. Pengambilan features selection dilakukan agar dimensi vektor kata menjadi lebih kecil. Kata-kata dengan bobot TF-IDF diurutkan secara descending dan kemudian diambil sesuai threshold tertentu. Persamaan 3 dan 4 menunjukan cara features selection. Kata-kata inilah yang nantinya akan digunakan pada proses clustering.

$$
\begin{aligned}
& \text { List of FS }=\operatorname{argmax}\left(\text { desc_sort }_{-}(\operatorname{TFIDF}(w i))\right) \\
& \text { List of Final FS }=\text { List of FS } \times \frac{\text { threshold }}{100}
\end{aligned}
$$

Tidak ada aturan khusus dalam penentuan threshold, user bisa menentukan threshold dalam skala 0 - 100\%. Sebagai contoh, misalnya telah didapatkan tabel features yang diurutkan secara descending berdasarkan nilai $t f$-idf seperti terlihat pada Tabel III dan user menentukan threshold sebesar 30\%. Maka penghitungannya adalah sebagai berikut:
List of Final FS $=10 \times \frac{30}{100}$
List of Final $F S=3$ 
Dari perhitungan tersebut, didapatkan jumlah features yang terpilih yaitu sebesar 3. Sehingga, mengacu pada Tabel III, maka kata-kata yang dimasukkan ke dalam vektor adalah 3 kata teratas yaitu "Prabowo", "Jokowi", dan "Dua". Sedangkan tujuh kata lainnya tidak dimasukkan ke dalam vektor, sehingga tidak digunakan dalam proses clustering.

TABEL III

CONTOH TABEL FEATURES

\begin{tabular}{|c|l|c|}
\hline No & \multicolumn{1}{|c|}{ Features } & TF-IDF \\
\hline $\mathbf{1}$ & Prabowo & 0,0370179 \\
\hline $\mathbf{2}$ & Jokowi & 0,0321342 \\
\hline $\mathbf{3}$ & Dua & 0,0272157 \\
\hline $\mathbf{4}$ & Indonesia & 0,0261607 \\
\hline $\mathbf{5}$ & Presiden & 0,0235883 \\
\hline $\mathbf{6}$ & Satu & 0,0227553 \\
\hline $\mathbf{7}$ & Pilih & 0,0220397 \\
\hline $\mathbf{8}$ & Harga & 0,0217826 \\
\hline $\mathbf{9}$ & Rakyat & 0,0197233 \\
\hline $\mathbf{1 0}$ & Tertawa & 0,0195362 \\
\hline
\end{tabular}

7) Clustering: Tahap berikutnya adalah proses clustering. Proses clustering pada tahap ini akan menerapkan dua algoritma yaitu K-Means dan Modified K-Means dengan tujuan untuk membandingkan dari segi purity dan konsistensi dari cluster yang dihasilkan.

Proses atau tahapan dari algoritma K-Means itu sendiri adalah sebagai berikut [13]:

1. Inisialisasi awal:

a. Input dataset $D=\left\{d_{1}, d_{2}, d_{3}, \ldots, d_{n}\right\}$

b. Set jumlah cluster $(k)$.

c. Ulangi sebanyak jumlah cluster:

- Pilih dokumen (datapoint) pada himpunan $D$ secara random sebagai centroid awal.

2. Ulangi hingga nilai centroid tidak terjadi perubahan:

a. Hitung jarak tiap dokumen dengan masing-masing centroid.

b. Masukkan dokumen ke dalam cluster yang memiliki jarak centroid (titik pusat cluster) terdekat.

c. Hitung ulang centroid baru pada setiap cluster.

3. Hasil akhir cluster telah didapat.

Sementara itu, tahapan dari algoritma Modified K-Means adalah sebagai berikut [5]:

1. Inisialisasi awal:

a. Input dataset $D=\left\{d_{1}, d_{2}, d_{3}, \ldots, d_{n}\right\}$

b. Set jumlah cluster $(k)$.

c. Ulangi sebanyak jumlah cluster:

- Hitung semua jarak antar dokumen satu dengan dokumen lainnya pada himpunan $D$.

- Temukan pasangan dokumen pada himpunan $D$ yang memiliki jarak terdekat.

- Masukkan pasangan dokumen tersebut ke dalam himpunan $C$ lalu hapus dari himpunan $D$.

- Ulangi hingga jumlah anggota himpunan $C$ mencapai $n / k$ :
- Temukan dokumen di himpunan $D$ yang memiliki jarak terdekat dengan himpunan $C$.

- Masukkan dokumen ke dalam himpunan $C$ lalu hapus dari himpunan $D$.

- Hitung rata-rata vektor dari tiap dokumen di himpunan $C$ dan tentukan sebagai centroid awal.

2. Ulangi hingga nilai centroid tidak terjadi perubahan:

a. Hitung jarak tiap dokumen dengan masing-masing centroid.

b. Masukkan dokumen ke dalam cluster yang memiliki jarak centroid (titik pusat cluster) terdekat.

c. Hitung ulang centroid baru pada setiap cluster.

3. Hasil akhir cluster telah didapat.

Untuk menentukan jarak antar dokumen digunakan rumus Euclidean Distance berikut [13] seperti pada Persamaan 5:

$$
d(i, j)=\sqrt{\left(\left|x_{i 1}-x_{j 1}\right|^{2}+\cdots+\left|x_{i n}-x_{j n}\right|^{2}\right)}
$$

Dimana:

$\begin{array}{ll}d(i, j) & =\text { jarak dokumen ke }-i \text { ke dokumen ke }-j \\ x_{i n} & =\text { nilai bobot kata ke }-n \text { di dokumen ke }-i \\ x_{j n} & =\text { nilai bobot kata ke }-n \text { di dokumen ke }-j\end{array}$

Sedangkan untuk menghitung nilai centroid baru pada tiap cluster, digunakan rumus pada Persamaan 6 [14]:

$$
c_{i}=\left(\frac{1}{m_{i}}\right) \sum_{x \in C_{i}} x
$$

Dimana:

$c_{i}=$ nilai centroid dari cluster $C_{i}$

$m_{i} \quad=$ jumlah dokumen yang berada dalam cluster ke - $i$

$x=$ nilai vektor dari sampel dokumen ke $-i$

\section{Rancangan Pengujian}

Dataset sebanyak 3400 komentar akan diambil beberapa saja untuk dijadikan sampel. Pengambilan sampel dilakukan secara seimbang antara label satu dan label lainnya. Proses pengambilan data dilakukan dengan cara mencari label yang memiliki jumlah komentar paling sedikit, lalu jumlah tersebut akan dijadikan sebagai patokan banyaknya jumlah komentar yang akan dipilih pada label yang lainnya. Misalnya label yang memiliki jumlah komentar paling sedikit adalah label netral dengan jumlah komentar sebanyak 100, maka label positif dan negatif masing-masing akan diambil 100 komentar sebagai data sampel. Proses pengambilan komentar dilakukan secara random.

Kemudian pengujian dilakukan menggunakan jumlah persentase features selection yang meningkat setiap tahapnya yaitu mulai dari 10\%, 20\%, 30\% sampai dengan $100 \%$. Selain itu, dalam pengujian ini juga akan membandingkan dua algoritma clustering yang digunakan yaitu K-Means dan Modified K-Means. 
Alat ukur pengujian yang akan digunakan adalah nilai purity dari cluster yang dihasilkan. Purity merupakan suatu ukuran evaluasi yang sederhana dan transparan. Purity dihitung dengan cara menjumlahkan dokumen yang berada di cluster yang tepat lalu dibagi dengan $N$ (jumlah keseluruhan dokumen) [6].

Purity bisa dihitung dengan menggunakan rumus pada Persamaan 7 [15]:

$$
\operatorname{Purity}(P, \mathrm{C})=\frac{1}{N} \sum_{k} \max _{j}\left|p_{k} \cap c_{j}\right|
$$

Dimana:

$$
\begin{aligned}
P= & \text { himpunan } \text { cluster }\left\{p_{1}, p_{2}, p_{3}, \ldots, p_{k}\right\} \\
C= & \text { himpunan } \quad \text { kelas } \quad \text { cluster }) \\
& \left\{C_{1}, C_{2}, C_{3}, \ldots, C_{j}\right\} \\
p_{k}= & \text { himpunan data/dokumen pada cluster } p_{k} \\
c_{j}= & \text { himpunan data/dokumen pada kelas acuan } c_{j}
\end{aligned}
$$

Sebagai contoh, misalnya diperoleh hasil clustering seperti pada Gambar 1 berikut [15]:

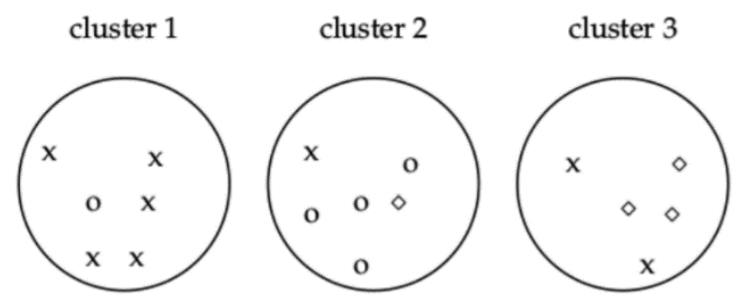

$$
\text { Gambar 1. Contoh hasil cluster }
$$

Pada Gambar 1, dapat dilihat bahwa mayoritas kelas dan jumlah anggota dari mayoritas kelas pada ketiga cluster tersebut adalah $\mathrm{x}=5$ (cluster 1$), \mathrm{o}=4$ (cluster 2$)$ dan $\diamond=3$ (cluster 3). Sedangkan total anggota pada keseluruhan cluster sama dengan $\mathrm{N}=17$. Sehingga, penghitungan nilai purity-nya adalah sebagai berikut:

$$
\text { Purity }=\frac{1}{17} \times(5+4+3)=0,71
$$

Clustering yang buruk mempunyai nilai purity mendekati 0 , sedangkan clustering yang sempurna memiliki nilai purity sebesar 1 [15].

Selain menganalisis kualitas cluster dari kedua metode berdasarkan besarnya nilai purity, penelitian ini juga akan membandingkan konsistensi hasil clustering dari kedua metode. Konsistensi yang dimaksud adalah untuk melihat apakah cluster yang dihasilkan berubah jika dilakukan beberapa kali pengujian clustering dengan atribut-atribut yang sama persis. Oleh karena itu, pada penelitian ini akan dilakukan pengujian clustering pada masing-masing metode sebanyak 5 kali, dengan ketentuan yang sama dan data sampel yang sama persis.

\section{HASIL DAN ANALISIS}

Bagian ini akan membahas mengenai hasil pengujian serta analisis cluster yang dihasilkan oleh kedua metode yaitu K-Means dan Modified K-Means.

\section{A. Hasil Pengujian}

Bagian ini membahas tentang hasil pengujian dari dua metode yaitu K-Means dan Modified K-Means.

Tabel IV merupakan hasil pengujian pada metode $K$ Means. Dari 10 pengujian dengan jumlah persentase features selection yang meningkat, rata-rata nilai purity dari hasil cluster yang diperoleh sebesar 0,391 atau 39,1\%.

TABEL IV

HASIL PENGUJIAN $K$-MEANS

\begin{tabular}{|c|c|c|c|c|c|c|c|c|c|c|}
\hline \multirow{2}{*}{$\begin{array}{c}\text { Feature } \\
\text { Selection } \\
(\%)\end{array}$} & Purity & \multicolumn{8}{|c|}{ Jumlah Komentar } \\
\hline & & \multicolumn{3}{|c|}{ Cluster 1 } & \multicolumn{3}{c|}{ Cluster 2 } & \multicolumn{3}{c|}{ Cluster 3 } \\
\hline & + & - & $\mathbf{N}$ & + & - & $\mathbf{N}$ & + & - & $\mathbf{N}$ \\
\hline 10 & 0,44 & 91 & 77 & 45 & 0 & 0 & 2 & 1 & 0 & 0 \\
\hline 20 & 0,41 & 100 & 87 & 58 & 0 & 0 & 1 & 1 & 0 & 0 \\
\hline 30 & 0,40 & 1 & 2 & 3 & 98 & 85 & 65 & 6 & 7 & 0 \\
\hline 40 & 0,39 & 104 & 99 & 73 & 0 & 0 & 2 & 4 & 0 & 0 \\
\hline 50 & 0,39 & 112 & 101 & 80 & 0 & 1 & 2 & 1 & 3 & 2 \\
\hline 60 & 0,38 & 0 & 1 & 2 & 114 & 104 & 90 & 1 & 0 & 0 \\
\hline 70 & 0,37 & 0 & 1 & 0 & 5 & 3 & 4 & 111 & 104 & 92 \\
\hline 80 & 0,37 & 113 & 117 & 90 & 0 & 0 & 1 & 2 & 1 & 3 \\
\hline 90 & 0,39 & 100 & 112 & 103 & 0 & 0 & 1 & 17 & 4 & 0 \\
\hline 100 & 0,37 & 0 & 1 & 0 & 105 & 112 & 107 & 14 & 7 & 0 \\
\hline
\end{tabular}

Sementara itu, Tabel V merupakan hasil dari pengujian pada metode Modified K-Means. Rata-rata nilai purity dari cluster yang dihasilkan sebesar 0,42 atau $42 \%$.

TABEL V

Hasil Pengujian Modified K-MEANS

\begin{tabular}{|c|c|c|c|c|c|c|c|c|c|c|}
\hline \multirow{2}{*}{$\begin{array}{c}\text { Feature } \\
\text { Selection } \\
(\%)\end{array}$} & Purity & \multicolumn{8}{|c|}{ Jumlah Komentar } \\
\cline { 3 - 12 } & & \multicolumn{3}{|c|}{ Cluster 1 } & \multicolumn{3}{c|}{ Cluster 2 } & \multicolumn{3}{c|}{ Cluster 3 } \\
\hline & + & - & $\mathbf{N}$ & + & - & $\mathbf{N}$ & + & - & $\mathbf{N}$ \\
\hline 10 & 0,45 & 66 & 72 & 39 & 20 & 15 & 0 & 1 & 1 & 6 \\
\hline 20 & 0,43 & 77 & 81 & 52 & 17 & 4 & 0 & 7 & 2 & 7 \\
\hline 30 & 0,42 & 81 & 87 & 59 & 17 & 4 & 0 & 7 & 3 & 9 \\
\hline 40 & 0,42 & 84 & 91 & 64 & 17 & 4 & 0 & 7 & 4 & 11 \\
\hline 50 & 0,42 & 89 & 98 & 72 & 17 & 4 & 0 & 7 & 3 & 12 \\
\hline 60 & 0,42 & 90 & 98 & 78 & 18 & 4 & 0 & 7 & 3 & 14 \\
\hline 70 & 0,41 & 91 & 101 & 85 & 18 & 4 & 0 & 7 & 3 & 11 \\
\hline 80 & 0,41 & 92 & 105 & 88 & 18 & 4 & 0 & 7 & 4 & 11 \\
\hline 90 & 0,41 & 92 & 108 & 91 & 18 & 4 & 0 & 7 & 4 & 13 \\
\hline 100 & 0,41 & 96 & 110 & 93 & 18 & 5 & 0 & 7 & 4 & 14 \\
\hline
\end{tabular}

B. Analisis Perbandingan Nilai Purity K-Means dan Modified K-Means 


\section{Perbandingan Nilai Purity \\ K-means vs Modified K-means}

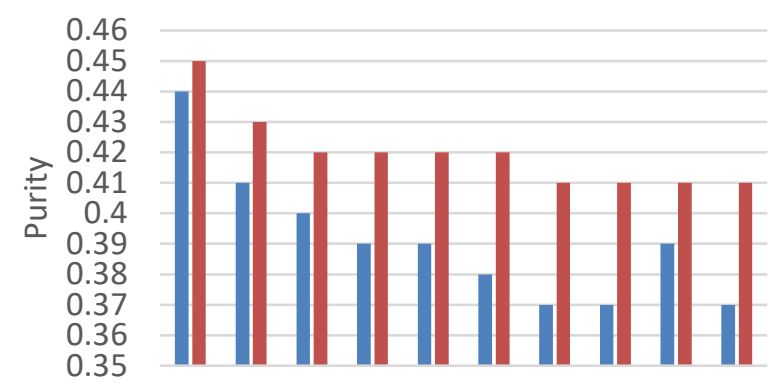

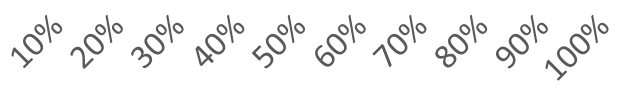

Features Selection

- K-Means Modified K-Means

Gambar 2. Grafik perbandingan nilai purity K-Means dan Modified $K$ Means

Gambar 2 merupakan grafik perbandingan antara metode $K$-Means dan Modified K-Means secara menyeluruh berdasarkan pada peningkatan features selection. Dari hasil pengujian tersebut, dapat dilihat bahwa Modified K-Means memiliki nilai purity yang lebih tinggi dibanding hasil clustering pada metode $K$-Means biasa. Sementara itu, jika di rata-rata, Modified $K$-Means menghasilkan rata-rata nilai purity sebesar 0,42 atau $42 \%$, sedangkan metode $K$-Means menghasilkan rata-rata nilai purity sebesar 0,391 atau 39,1\% sehingga terjadi peningkatan kualitas cluster sebesar 2,9\%. Untuk lebih jelasnya, dapat dilihat pada grafik rata-rata nilai purity pada Gambar 3.

\section{Perbandingan Rata-Rata Nilai Purity K-Means vs Modified K-means}

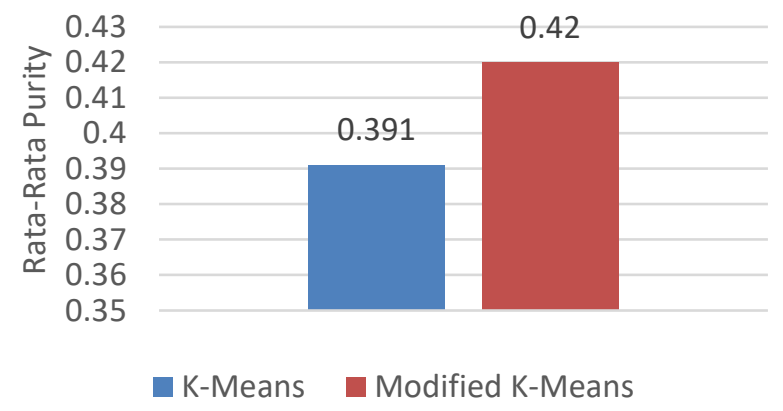

Gambar 3. Grafik perbandingan rata-rata nilai purity antara K-Means dan Modified K-Means

Dari hasil pengujian ini, dapat disimpulkan bahwa metode Modified K-Means mampu menghasilkan kualitas cluster yang lebih baik berdasarkan pada nilai purity yang dihasilkan.

\section{Pengujian Konsistensi Hasil Cluster}

Setelah menganalisis kualitas cluster dari kedua metode berdasarkan besarnya nilai purity, analisis selanjutnya yaitu membandingkan kualitas hasil clustering dari kedua metode berdasarkan konsistensi cluster yang dihasilkan. Analisis yang dimaksud adalah untuk melihat apakah cluster yang dihasilkan berubah jika dilakukan beberapa kali clustering dengan atribut-atribut yang sama persis. Pengujian akan dilakukan sebanyak 5 kali.

Tabel VI menunjukkan rangkuman dari 5 kali pengujian yang telah dilakukan pada metode K-Means. Pada Tabel VI, dapat dilihat bahwa selain nilai purity yang dihasilkan, anggota-anggota dari cluster yang dihasilkan juga selalu berubah setiap kali dilakukan pengujian. Dari hasil ini, maka dapat disimpulkan bahwa metode K-Means menghasilkan cluster yang tidak konsisten atau selalu berubah-ubah. Perubahan cluster yang dihasilkan juga mempengaruhi nilai purity yang juga ikut berubah.

TABEL VI

Hasil Pengujian Konsistensi Hasil Clustering Pada Metode $K$ MEANS

\begin{tabular}{|c|c|c|c|c|c|c|c|c|c|c|}
\hline \multirow{2}{*}{$\begin{array}{c}\text { Pengujian } \\
\text { ke- }\end{array}$} & Purity & \multicolumn{10}{|c|}{ Jumlah Komentar } \\
\cline { 3 - 12 } & & \multicolumn{3}{|c|}{ Cluster 1 } & \multicolumn{3}{c|}{ Cluster 2 } & \multicolumn{3}{c|}{ Cluster 3 } \\
\cline { 3 - 11 } & + & - & $\mathbf{N}$ & + & - & $\mathbf{N}$ & + & - & N \\
\hline 1 & 0,43 & 72 & 78 & 44 & 0 & 2 & 1 & 15 & 8 & 0 \\
\hline 2 & 0,41 & 1 & 1 & 2 & 0 & 0 & 1 & 86 & 87 & 42 \\
\hline 3 & 0,41 & 80 & 82 & 43 & 0 & 0 & 1 & 7 & 6 & 1 \\
\hline 4 & 0,40 & 1 & 2 & 0 & 0 & 0 & 1 & 86 & 86 & 44 \\
\hline 5 & 0,40 & 85 & 86 & 42 & 0 & 0 & 1 & 2 & 2 & 2 \\
\hline
\end{tabular}

Sementara itu, rangkuman pengujian konsistensi pada metode Modified K-Means dapat dilihat pada Tabel VII. Pada Tabel VII, dapat dilihat bahwa dari 5 kali pengujian yang dilakukan, baik nilai purity maupun cluster yang dihasilkan tidak pernah berubah. Hal ini terjadi karena pada Modified K-Means, centroid awal ditentukan menggunakan algoritma modified centroid Selection dimana tidak terdapat faktor random, sehingga selalu menghasilkan centroid awal yang sama. Sedangkan pada metode K-Means, centroid awal ditentukan secara random, sehingga centroid awal memungkinkan untuk berubah-ubah dan mempengaruhi hasil clustering yang juga berubah-ubah.

TABEL VII

Hasil Pengujian Konsistensi Hasil CLUSTERING PAda Metode $K$ MEANS

\begin{tabular}{|c|c|c|c|c|c|c|c|c|c|c|}
\hline Pengujian & Purity \\
ke- & & \multicolumn{10}{|c|}{ Jumlah Komentar } \\
\cline { 3 - 11 } & & \multicolumn{3}{|c|}{ Cluster 1 } & \multicolumn{3}{c|}{ Cluster 2 } & \multicolumn{3}{c|}{ Cluster 3 } \\
\cline { 3 - 11 } & + & - & $\mathbf{N}$ & + & - & $\mathbf{N}$ & + & - & N \\
\hline 1 & 0,45 & 66 & 72 & 39 & 20 & 15 & 0 & 1 & 1 & 6 \\
\hline 2 & 0,45 & 66 & 72 & 39 & 20 & 15 & 0 & 1 & 1 & 6 \\
\hline 3 & 0,45 & 66 & 72 & 39 & 20 & 15 & 0 & 1 & 1 & 6 \\
\hline 4 & 0,45 & 66 & 72 & 39 & 20 & 15 & 0 & 1 & 1 & 6 \\
\hline 5 & 0,45 & 66 & 72 & 39 & 20 & 15 & 0 & 1 & 1 & 6 \\
\hline
\end{tabular}


Dari pengujian ini, dapat disimpulkan jika metode Modified K-Means menghasilkan cluster yang konsisten karena tidak ada faktor random, sedangkan metode $K$ Means menghasilkan cluster dan nilai purity yang tidak konsisten atau berubah-ubah yang juga ikut mempengaruhi kualitas cluster yang dihasilkan.

\section{Analisis Nilai Purity}

Dari hasil pengujian pada kedua metode yang bisa dilihat pada Tabel III dan Tabel IV, rata-rata nilai purity yang dihasilkan kurang dari 0,5 atau kurang dari 50\%. Rendahnya nilai purity ini disebabkan oleh dataset itu sendiri, lebih spesifiknya karena dari pemberian label komentar yang didasarkan pada pembuat status (Jokowi atau Prabowo). Hal ini bisa dibuktikan dengan adanya beberapa komentar yang cenderung identik namun memiliki label yang berbeda. Misalnya komentar "salam 2 jari", jika komentar ditujukan pada status pasangan nomor urut 1 , maka labelnya akan negatif, sedangkan jika ditujukan pada status pasangan nomor urut 2, maka labelnya positif. Contoh kasus ini bisa dilihat pada Gambar 4 yang merupakan hasil dari salah satu cluster yang sebenarnya sangat identik namun memiliki label yang berbeda.

\begin{tabular}{|c|c|c|}
\hline Id Komentar & Komentar & Label \\
\hline 1053 & salam 2 jari :-) & negatif \\
\hline 1310 & Slam 2 jarii & negatif \\
\hline 1316 & Salam 2jari & negatif \\
\hline 1367 & salam 2 jari & negatif \\
\hline 2384 & wonosobo hadir $\operatorname{sim} 2$ ji & positif \\
\hline 2515 & Sukseses selalu pak _, salam 2 jari & positif \\
\hline 2603 & Salam 2 jari & positif \\
\hline 2604 & salam 2 jari & positif \\
\hline 2608 & salam 2 jari & positif \\
\hline 2612 & Salam 2 jari & positif \\
\hline 2640 & SIm 2 iari & nne itiff \\
\hline
\end{tabular}

Gambar 4. Contoh cluster yang memiliki komentar identik dengan label berbeda

Selain masalah pada pelabelan, berdasarkan pada hasil pengamatan, penyebab kecilnya nilai purity yang dihasilkan kemungkinan terletak pada jumlah cluster yang ditetapkan. Pada penelitian ini, jumlah cluster yang ditetapkan sebanyak 3 sesuai dengan jumlah label yang ada. Namun, pada implementasinya, dalam satu cluster masih terdapat komentar-komentar yang masih bisa dipecah atau dikelompokkan lagi ke dalam cluster yang berbeda.

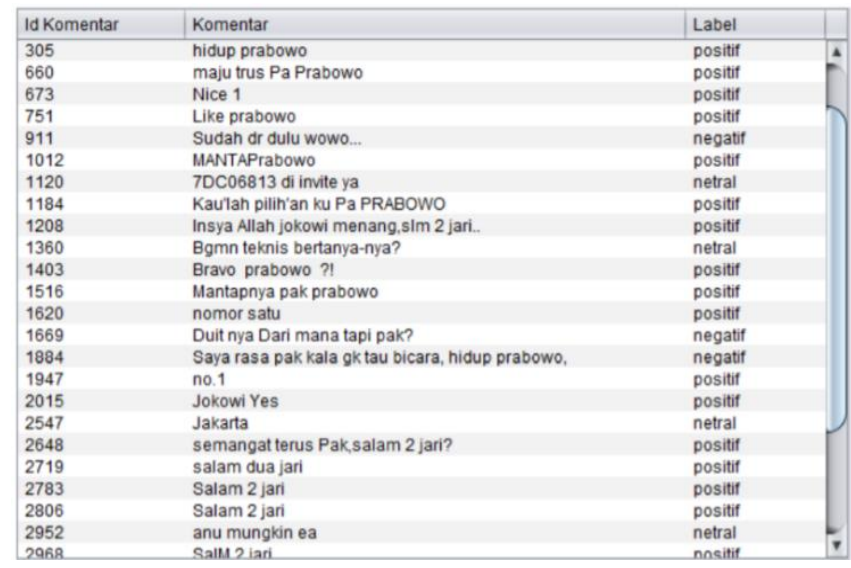

Gambar 5. Contoh cluster yang masih bisa dikelompokkan lagi

Gambar 5 merupakan contoh komentar-komentar dalam salah satu cluster yang masih bisa dikelompokkan lagi berdasarkan kemiripannya. Misalnya komentar-komentar seperti "hidup prabowo", "like prabowo" dan sejenisnya bisa berada dalam cluster sendiri, lalu komentar seperti "salam 2 jari" juga bisa dikelompokkan ke dalam cluster yang berbeda. Dari pengamatan tersebut, kurangnya jumlah cluster yang ditetapkan kemungkinan menjadi salah satu penyebab buruknya kualitas cluster yang dihasilkan.

Sebagai pembuktian hasil analisis mengenai penyebab kecilnya nilai purity yang dihasilkan, dilakukan dua pengujian yaitu yang pertama adalah pengujian ulang dengan menggunakan data label yang sudah diperbaiki secara manual berdasarkan interpretasi sendiri, kemudian selanjutnya adalah pengujian dengan menggunakan jumlah cluster yang meningkat dari 3, 4, 5, 6 dan 7 .

Berdasarkan pada hasil analisis sebelumnya mengenai perbandingan dari kedua metode, maka pengujian ini akan menggunakan metode Modified K-Means. Pengujian pada data label yang telah diperbaiki akan dibandingkan dengan pengujian sebelumnya yang dapat dilihat pada Tabel V, dimana perbandingan ini dilakukan untuk melihat apakah perbaikan label berpengaruh pada nilai purity yang dihasilkan. Sedangkan pada pengujian jumlah cluster bertujuan untuk melihat apakah dengan meningkatnya jumlah cluster juga bisa meningkatkan kualitas cluster yang diukur dari nilai purity yang dihasilkan.

1) Pengujian pada Perbaikan Label: Hasil pengujian dengan menggunakan data label yang telah diperbaiki bisa dilihat pada Tabel VIII. Dari 10 pengujian yang dilakukan berdasarkan persentase feature selection, rata-rata nilai purity yang dihasilkan yaitu sebesar 0,425 . Hasil ini lebih besar dari hasil pengujian pada data label yang belum diperbaiki yaitu sebesar 0,42 yang bisa dilihat pada Tabel V. 
TABEL VIII

HASIL PENGUJIAN MODIFIED K-MEANS DENGAN PERBAIKAN LABEL DAN JUMLAH CLUSTER 3

\begin{tabular}{|c|c|}
\hline $\begin{array}{c}\text { Feature Selection } \\
\text { Threshold }(\%)\end{array}$ & Purity \\
\hline 10 & 0,47 \\
\hline 20 & 0,43 \\
\hline 30 & 0,43 \\
\hline 40 & 0,42 \\
\hline 50 & 0,42 \\
\hline 60 & 0,41 \\
\hline 70 & 0,41 \\
\hline 80 & 0,42 \\
\hline 90 & 0,42 \\
\hline 100 & 0,42 \\
\hline
\end{tabular}

Gambar 6 merupakan grafik perbandingan nilai purity hasil clustering pada metode Modified K-Means yang menggunakan data label sebelum dan setelah diperbaiki. Dari hasil perbandingan tersebut, dapat dilihat jika perbaikan label dapat meningkatkan nilai purity, namun tidak begitu signifikan. Dimana peningkatan yang terjadi hanya sebesar $0,5 \%$.

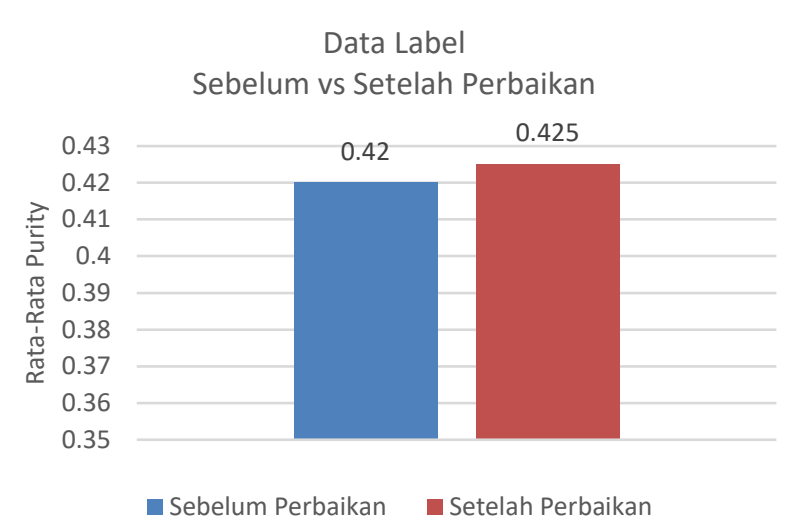

Gambar 6. Grafik perbandingan rata-rata nilai purity sebelum dan setelah perbaikan label

2) Pengujian pada Penambahan Jumlah Cluster: Pengujian jumlah cluster bertujuan untuk melihat apakah dengan meningkatnya jumlah cluster juga bisa meningkatkan kualitas cluster yang diukur dari nilai purity yang dihasilkan. Pengujian dilakukan dengan jumlah cluster 3, 4, 5, 6 dan 7 .

Dari hasil pengujian sebelumnya mengenai perbaikan label, maka pengujian mengenai penambahan jumlah cluster akan menggunakan data label yang telah diperbaiki. Pengujian pada jumlah cluster sebesar 3 menggunakan hasil pengujian sebelumnya yang bisa dilihat pada Tabel VIII.

Sementara itu, hasil pengujian menggunakan jumlah cluster sebesar 4 dapat dilihat pada Tabel IX. Hasil pengujian pada jumlah cluster sebesar 4 menghasilkan ratarata nilai purity sebesar 0,433 , dimana hasil ini lebih besar dari rata-rata nilai purity yang dihasilkan pada jumlah cluster sebesar 3 dengan rata-rata purity sebesar 0,425.

TABEL IX

HaSil PENGUJian ModifiEd K-MEANS DENGAN PERBAIKAN LABEL DAN JUMLAH CLUSTER 4

\begin{tabular}{|c|c|}
\hline $\begin{array}{c}\text { Feature Selection } \\
\text { Threshold }(\%)\end{array}$ & Purity \\
\hline 10 & 0,47 \\
\hline 20 & 0,45 \\
\hline 30 & 0,44 \\
\hline 40 & 0,44 \\
\hline 50 & 0,42 \\
\hline 60 & 0,42 \\
\hline 70 & 0,42 \\
\hline 80 & 0,42 \\
\hline 90 & 0,43 \\
\hline 100 & 0,42 \\
\hline
\end{tabular}

Kemudian hasil pengujian menggunakan jumlah cluster sebesar 5 dapat dilihat pada Tabel X Hasil pengujian pada jumlah cluster sebesar 5 menghasilkan rata-rata nilai purity sebesar 0,435, dimana hasil ini lebih besar dari rata-rata nilai purity yang dihasilkan pada jumlah cluster sebesar 4 dengan rata-rata purity sebesar 0,433 .

TABEL $X$

Hasil PENGUJian MODIFIED K-MEANS DENGAN PERBAIKAN LABEL DAN JUMLAH CLUSTER 5

\begin{tabular}{|c|c|}
\hline $\begin{array}{c}\text { Feature Selection } \\
\text { Threshold }(\%)\end{array}$ & Purity \\
\hline 10 & 0,49 \\
\hline 20 & 0,44 \\
\hline 30 & 0,44 \\
\hline 40 & 0,44 \\
\hline 50 & 0,43 \\
\hline 60 & 0,42 \\
\hline 70 & 0,42 \\
\hline 80 & 0,42 \\
\hline 90 & 0,42 \\
\hline 100 & 0,43 \\
\hline
\end{tabular}

Lalu, Tabel XI menunjukkan hasil pengujian menggunakan jumlah cluster sebesar 6. Hasil pengujian pada jumlah cluster sebesar 6 menghasilkan rata-rata nilai purity sebesar 0,438 , dimana hasil ini lebih besar dari ratarata nilai purity yang dihasilkan pada jumlah cluster sebesar 5 dengan rata-rata purity sebesar 0,435 .

TABEL XI

Hasil PENGUJian Modified $K$-MEANS DENGAN PERBAIKAN LABEL DAN JUMLAH CLUSTER 6

\begin{tabular}{|c|c|}
\hline $\begin{array}{c}\text { Feature Selection } \\
\text { Threshold }(\boldsymbol{\%})\end{array}$ & Purity \\
\hline 10 & 0,51 \\
\hline 20 & 0,45 \\
\hline 30 & 0,44 \\
\hline 40 & 0,45 \\
\hline 50 & 0,46 \\
\hline 60 & 0,42 \\
\hline
\end{tabular}




\begin{tabular}{|c|c|}
\hline $\begin{array}{c}\text { Feature Selection } \\
\text { Threshold } \mathbf{( \% )}\end{array}$ & Purity \\
\hline 70 & 0,42 \\
\hline 80 & 0,41 \\
\hline 90 & 0,41 \\
\hline 100 & 0,41 \\
\hline
\end{tabular}

Selanjutnya, Tabel XII menunjukkan hasil pengujian menggunakan jumlah cluster sebesar 7. Hasil pengujian pada jumlah cluster sebesar 7 menghasilkan rata-rata nilai purity sebesar 0,47 , dimana hasil ini lebih besar dari ratarata nilai purity yang dihasilkan pada jumlah cluster sebesar 6 dengan rata-rata purity sebesar 0,438 .

TABEL XII

HASIL PENGUJIAN MODIFIED K-MEANS DENGAN PERBAIKAN LABEL DAN JUMLAH CLUSTER 7

\begin{tabular}{|c|c|}
\hline $\begin{array}{c}\text { Feature Selection } \\
\text { Threshold (\%) }\end{array}$ & Purity \\
\hline 10 & 0,51 \\
\hline 20 & 0,48 \\
\hline 30 & 0,50 \\
\hline 40 & 0,49 \\
\hline 50 & 0,48 \\
\hline 60 & 0,45 \\
\hline 70 & 0,45 \\
\hline 80 & 0,45 \\
\hline 90 & 0,44 \\
\hline 100 & 0,45 \\
\hline
\end{tabular}

Dari hasil pengujian dengan menggunakan jumlah cluster yang berbeda yang bisa dilihat pada Tabel VIII sampai Tabel XII, dilakukan perbandingan rata-rata nilai purity yang dihasilkan. Perbandingan tersebut bisa dilihat pada grafik perbandingan rata-rata nilai purity pada Gambar 7.

Pada Gambar 7, dapat dilihat bahwa penambahan jumlah cluster yang ditentukan dapat meningkatkan rata-rata nilai purity yang dihasilkan. Kemudian peningkatan yang paling signifikan terjadi pada jumlah cluster sebesar 7, dimana mengalami peningkatan sebesar 4,5\% dibandingkan dengan jumlah cluster semula yang sebesar 3. Dari hasil pengujian ini maka dapat disimpulkan bahwa beberapa penyebab kecilnya nilai purity yang dihasilkan yaitu karena masalah pada pelabelan dan kurangnya jumlah cluster yang ditetapkan.

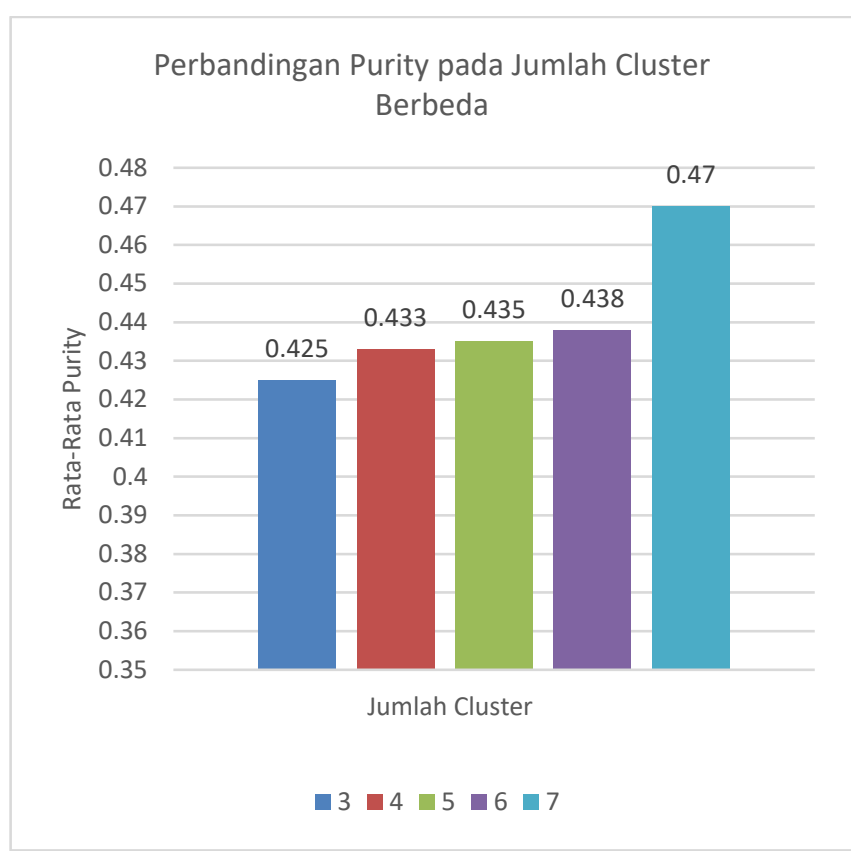

Gambar 7. Grafik perbandingan rata-rata nilai purity pada jumlah cluster yang berbeda

Pengujian pada perbaikan label dan penambahan jumlah cluster ini dilakukan bukan untuk mencari nilai purity yang terbaik, melainkan hanya untuk menganalisis penyebab buruknya kualitas cluster yang dihasilkan. Sehingga, masih diperlukan penelitian lebih lanjut untuk mencari jumlah cluster yang terbaik.

\section{KESIMPULAN}

Dari penelitian dan analisis yang telah dilakukan, dapat ditarik beberapa kesimpulan. Yang pertama yaitu dari segi konsistensi hasil cluster, dimana metode Modified K-Means mampu menghasilkan cluster yang lebih konsisten. Dari 5 kali pengujian dengan data yang sama, metode Modified $K$ Means yang dalam penerapannya menggunakan algoritma modified centroid Selection dalam menentukan centroid awal tidak mengalami perubahan sama sekali, baik dari segi purity maupun cluster yang dihasilkan. Sementara pada metode K-Means, selalu terjadi perubahan cluster pada setiap pengujian yang dilakukan sehingga mempengaruhi nilai purity yang dihasilkan.

Sementara itu, dari segi akurasi atau kualitas cluster, penerapan metode Modified K-Means pada pengelompokan data komentar sentipol menghasilkan cluster yang lebih baik berdasarkan pada nilai purity yang dihasilkan. Dimana pada penggunaan algoritma Modified K-Means menghasilkan rata-rata nilai purity sebesar 0,42 atau $42 \%$ sementara $K$ Means menghasilkan rata-rata nilai purity sebesar 0,391 atau $39,1 \%$. Namun, rata-rata persentase nilai purity yang dihasilkan masih dibawah 50\%. Hal ini disebabkan karena masalah pelabelan pada dataset dan kurangnya jumlah cluster yang ditetapkan. Dari hasil pengujian dengan label yang telah diperbaiki secara manual, terjadi 
peningkatan nilai purity sebesar 0,5\%. Sedangkan pada pengujian penambahan jumlah cluster, dari jumlah cluster sebesar 3 sampai dengan 7, selalu terjadi peningkatan nilai purity setiap kali jumlah cluster ditambah.

Secara umum, algoritma Modified K-Means yang memodifikasi pemilihan centroid awal, bisa digunakan untuk mengoptimalkan kinerja dari algoritma K-Means yang mana kualitas cluster yang dihasilkan bergantung pada pemilihan centroid awal. Selain itu, berdasarkan hasil analisis dari penelitian ini, masih bisa dilakukan penelitian lebih lanjut dalam menentukan jumlah cluster yang terbaik untuk lebih mengoptimalkan akurasi atau kualitas cluster yang dihasilkan.

\section{DAFTAR PUSTAKA}

[1] A. Rachmat \& Y. Lukito, "Sentipol: Dataset Sentimen Komentar pada Kampanye Pemilu Presiden Indonesia 2014 dari Facebook Page," Konferensi Nasional Teknologi Informasi dan Komunikasi, 2016, pp. 218-228.

[2] J. Han \& M. Kamber, Data Mining: Concepts and Techniques, 2nd ed., San Francisco: Elsevier, 2006.

[3] A. Alrabea, A. V. Senthilkumar, H. Al-Shalabi \& A. Bader, "Enhancing K-Means Algorithm with Initial Cluster Centers Derived from Data Partitioning along the Data Axis with PCA," Journal of Advances in Computer Networks, vol. 1, no. 2, pp. 137142, Jun. 2013.

[4] A. C. Fabregas, B. D. Gerardo \& B. T. Tanguilig III, "Enhanced Initial Centroids for K-Means Algorithm," International Journal of Information Technology and Computer Science, vol. 9, no. 1, pp. 2633, Jan. 4, 2017.

[5] S. Sujatha \& A. S. Sona, "New Fast K-Means Clustering Algorithm using Modified Centroid Selection Method," International Journal of Engineering Research \& Technology, vol. 2, no. 2, pp. 1-9, Feb. 2013.

[6] C. D. Manning, P. Raghavan \& H. Schutze, An Introduction to Information Retrieval, Cambridge: Cambridge University Press, 2009.

[7] Rudy, "Perbandingan Metode K-Means Dan Hierarchical Agglomerative Clustering untuk Pengelompokan Dokumen Teks," Undergraduate thesis, Duta Wacana Christian University, 2009.

[8] S. S. Raghuwanshi \& P. N. Arya, "Comparison of K-Means and Modified K-Mean Algorithms for Large Data-set," International Journal of Computing, Communications and Networking, vol. 1, no. 3, pp. 106-110, 2012.

[9] I. Safeek \& M. R. Kalideen, "Preprocessing on Facebook Data for

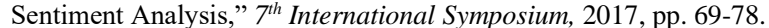

[10] J. Joseph \& J. R. Jeba, "Information Extaction Using Tokenization and Clustering Methods," International Journal of Recent Technology and Engineering, vol. 8, no. 4, pp. 3690-3692, Nov. 2019.

[11] J. K. Raulji \& J. R. Saini, "Stop-Word Removal Algorithm and its Implementation for Sanskrit Language," International Journal of Computer Applications, vol. 150, no. 2, pp. 15-17, Sept. 2016.

[12] H. Christian, M. P. Agus \& D. Suhartono, "Single Document Automatic Text Summarization using Term Frequency-Inverse Document Frequency (TF_IDF)," Computer, Mathematics and Engineering Applications, vol. 7, no. 4, pp. 285-294, Dec. 2016.

[13] T. Widiyaningtyas, M. I. W. Prabowo \& M. A. M Pratama, "Implementation of K-Means Clustering Method to Distribution of High School Teachers," in $4^{\text {th }}$ International Conference on Electrical Engineering, Computer Science and Informatics, 2017, pp. 49-54.

[14] F. L. Sibuea \& A. Sapta, "Pemetaan Siswa Berprestasi Menggunakan Metode K-Means Clustering," Jurnal Teknologi dan Sistem Informasi, vol. 4, no. 1, pp. 85-92, Dec. 2017.

[15] S. M. Kim, M. I. Pena, M. Moll, G. Giannakopoulos, G. N. Bennett \& L. E. Kavraki, "An Evaluation of Different Clustering Methods and Distance Measures Used for Grouping Metabolic Pathways," $8^{\text {th }}$ International Conference on Bioinformatics and Computational Biology, Las Vegas, 2016. 